\title{
Effect of vermicompost and phosphorus on nutrient content, uptake and quality in fenugreek (Trigonella foenum graceum L.)
}

\section{DINESH KUMAR AND YOGESH SHARMA}

\section{MEMBERS OF RESEARCH FORUM:}

Corresponding author :

DINESH KUMAR, Department of Soil Science and Agricultural Chemistry,

College of Agriculture, BIKANER (RAJASTHAN) INDIA

Email:dkrachiata@gmail.com

\section{Co-authors :}

YOGESH SHARMA, Department of Soil Science and Agricultural Chemistry, College of Agriculture, BIKANER (RAJASTHAN) INDIA
Received : 29.09.2014; Revised : 30.10.2014; Accepted : 16.11.2014

\section{Summary}

A field experiment was conducted on loamy sand soil during Rabi season of 2009-10 to study the effect of verimcompost and phosphorus on nutrient content, uptake and quality in fenugreek (Trigonella foenum graceum L.). Application of $4.0 \mathrm{t}$ vermicompost significantly increased the nitrogen content in seed, protein content, nitrogen uptake in seed and straw. While application of $6.0 \mathrm{t}$ vermicompost ha ${ }^{-1}$ significantly increased the phosphorus content in seed, straw, phenol content, total nitrogen uptake, phosphorus uptake in seed, straw and total. Application of $2.0 \mathrm{t}$ vermicompost ha ${ }^{-1}$ significantly increased the nitrogen content in seed, straw. Application of $40 \mathrm{~kg}$ phosphorus ha- ${ }^{-1}$ significantly increased the nitrogen content in seed, straw, phosphorus content in straw, protein content in seed, nitrogen uptake in seed, straw, total and phosphorus uptake in straw. Application of $60 \mathrm{~kg}$ phosphorus ha $\mathrm{a}^{-1}$ significantly increased the phosphorus content in seed, phenol content, phosphorus uptake in seed and total.

Key words : Fenugreek, Vermicompost, Phosphorus, Nutrient content, Uptake, Quality

How to cite this article : Kumar, Dinesh and Sharma, Yogesh (2014). Effect of vermicompost and phosphorus on nutrient content, uptake and quality in fenugreek (Trigonella foenum graceum L.). Asian J. Soil Sci., 9(2): 276-279. 